\title{
FOREIGN LANGUAGES AS MEANS OF STUDENTS' PROFESSIONAL MOBILITY DEVELOPMENT
}

The paper considers the practical aspects of professional mobility development for students of higher school by means of foreign language. On the analysis of contemporary scientific-methodological works on professional education of future specialists at Ukrainian higher educational establishments, the author has emphasized that the full potential of foreign languages is not being realized, there is a lack of substantive and pedagogic support of the deliberate fostering of students' professional competency by means of a foreign language; the learning process on the discipline "Foreign language" takes place virtually entirely separately from the process of student's professional competency development, and as a result he/she has no comprehension of content of his/her future professional activities.

The author has determined the concept of "academic mobility" as one of the key component of social mobility and integrated quality of future experts' ability to master the main and professional competencies; the constant training and education in various kinds of future professional activity; successful career development and professional achievement for graduating students. The academic mobility is considered as significant life characteristic of a future specialist on the labour market as well as in the educational process, since different kinds of mobility have some influence on improvements in efficiency in distribution of labour resources.

The article analyzes the existing experience of teaching English at higher educational establishments using CLIL (Content and Language Integrated Learning) approach. The article suggests the ways of professional mobility development by means of foreign language. It discusses the advantages of innovative teaching, which is aimed at meeting the professional and educational needs of students, the development of professional mobility and creative thinking. It is concluded that studying a foreign language and non-language subject at the same time is an additional means to achieve high educational outcomes, namely the practical application of CLIL methodology would considerably enhance the studens' motivation to learn foreign languages, teach them knowingly and freely use a foreign language in everyday communication; broaden their mind, knowledge and acceptance of the other cultures and values through educational activities in formal and extra-curricular frameworks; prepare students for further education in the area of science; develop and improve linguistic and communicative competencies by learning foreign languages.

Key words: academic mobility, European Transfer and Accumulating System(ECTS), Content and Language Integrated Learning (CLIL), communicative competence, foreign language, higher educational establishment.

Formulation of the problem. Overview of higher education support programs and most resent reports of European Commission shows that mobility is key to building European educational and scientific space, with the aim of creating conditions for improving educational access for everyone in society anytime and anywhere. The rapid developments in information and communication technologies, in particular the Internet, offer a unique opportunity for emergence and development of innovative technologies of distance education, blended learning, e-learning and mobile learning. The latest technology represents the key aspects of European Higher Education Area (EHEA) development: mobility of all subjects of educational process, the continuity of education, lifelong learning, and the training targeted to a personality, innovativeness, social- constructionist learning approach to the organization of education etc.

Mobility is a modern interdisciplinary paradigm in social sciences and the humanities, monitoring the movement of people, things and ideas, and as well as consequences of these movements. Furthermore, the movement itself cannot only be real (geographical mobility or physical movement of the objects), but can also be just virtual (virtual tours, excursions and so on), by providing young people with the opportunity to lead a more "mobile life" despite the physical (substantive, social etc.) limitations. A person can have the high level of virtual mobility through mobile communications without the need for physical movement (a remote work with a high level of professional, social and economical mobility), but he/she can obtain a high degree of geographical mobility without changing the personal choice and competency.

Nowadays, academic mobility of students is of significance as not only a mechanism for successful integration of Ukrainian higher educational establishments into the international educational space, but it also provided access to more progressive educational programmes and guarantees research capacity; it is becoming a factor, improving the quality in higher education and creating new labour force. In 
heavy development of global labour market, mobility is conceived essentially as a competitive advantage of a specialist. Various types of mobility (social, career, educational, professional etc.) contribute to the effectiveness and efficiency of distribution of labour resources. In the international community, mobility is a significant life characteristic of a future specialist on the labour market as well as in the educational process, since different kinds of mobility have some influence on improvements in efficiency in distribution of labour resources.

Analysis of actual researches. Ukraine became part of a process to develop European Higher Education Area when programmes of international academic mobility had functioned for several decades in European countries, which are executed by means of federal structures and independent academic foundations and institutions. Just a few years ago, Ukrainian researchers have come to see professional mobility as being important professional quality of a graduate of a higher school and necessary characteristic in the labour market.

Regulations on the significance of mobility are outlined in the following Bologna documents "Great Charter of Universities", "Sorbonne Declaration", "Bologna Declaration", etc. A review of available scientific and educational literature has shown that O. Martynov consider the concept of academic mobility as the opportunity for students to move from one institution to another for the exchange of experience; $\mathrm{N}$. Brinev and R. Chuyanov define it as a studying period of a student in a foreign country; Council of Europe Committee of Ministers characterize academic mobility as moving someone for educational purposes for a definite period (usually a semester to a year) to another educational institution (local or foreign) for studying or research.

Now, analysis of integration arrangements implementing, assessments and comparison of their effectiveness is considered by researchers of the issue as a priority for a higher school. Ukrainian students are able to research, study and cooperate with famous European higher education institutions. Since today's society needs professionals with capacity to generate a positive impact, who generate new ideas and are practical when resolving problems in the labour, social, economic domains and who are proficient in foreign languages in partnership with foreign countries, the European Commission not only improves the existing educational programmes, but also actively introduces new advanced ones. Through international academic programmes such as "Erasmus Mundus", "Tempus", "Socrates", "Jean Monnet", providing essential guidance for enhancing the international partnership and promoting professional mobility, Ukrainian scientists, teachers and students may be trained and work abroad [2, p. 20-24].
There are, however, a number of problems associated with this issue, which need to be addressed. A review by Klahr and Rattiunder lines the importance of the inadequate recognition of periods abroad and credit transfer. Moreover, insufficient knowledge of educational prerequisites and qualifications of different countries, distinction between the structure of the training term and differences in the times at which exams are taken. These are all common challenges of credit mobile students when they deal with training activities. In addition, insufficient foreign language skills are regarded as a serious barrier to most of the mobile students, not only the credit mobile ones.

Scientists and methodologists are more and more focused on finding better ways of training process that are to develop in every future specialist the ability of constant self-perfection in his professional activities that will allow him/her greater flexibility in responding to every change in her/his career. Many studies of the international labor market have shown that the level of preparation of specialists of most common professions does not correspond to international standards due to insufficient specific skills and personal qualifications that a specialist should have in order to be competitive in the international labor market. In practice, one of the reasons for this is lacunae in specialists' knowledge of languages.

A particular concern is the need to re-evaluate the traditional approach to the teaching of foreign languages in higher school and to organize learning process in a manner that guarantees stronger competencies for a future specialist by means of foreign languages and supports their career development with a view to a successful development of future specialists' professional mobility. The educational process should be built upon the segregation of disciplines and strengthening the specialization, parallel integration in the learning process of common definitions to obtain consistent and coherent views of objects being studied.

The analysis of contemporary scientific-methodological works on professional education of future specialists at Ukrainian higher educational establishments indicated that the full potential of foreign languages was not being realized, there was a lack of substantive and pedagogic support of the deliberate fostering of students' professional competency by means of a foreign language; the learning process on the discipline "Foreign language" takes place virtually entirely separately from the process of student's professional competency development, and as a result he/she has no comprehension of content of his/her future professional activities [3, p. 93].

The aim of this article is to disclose a role of foreign language learning at a high school in the process of professional mobility development of a future specialist, to determine the merits and the shortcomings 
of techniques CLIL (content and language integrated learning) in academic process, to cover the vocational training needs of students and to develop their professional mobility.

Presentation of the main material. The importance to develop a linguistic competence of a future specialist is required by time. Long-term monitoring has enabled the scientists to assert that professional mobility is not developed and does not show up in the structure of the student's personality independently. It should be formed knowingly and deliberately targeted. According to that view, a foreign language as a subject has a great capacity. At the moment teachers, being as managers of training process should not only develop the skills to assess and implement students' previous experiences in practice, but also form their skills to plan their own professional future. This includes providing sheer professionalism and the following indicators now determine competence of a future specialist, since the efficiency and the quality of higher vocational education as a rule: graduates' employability and their social status, the level of working portfolio and competitiveness of specialists in the labor market. Consequently, it is obvious that the training process in a higher educational establishment should be professionally oriented and its objectives should be tailored to fit the communicative and cognitive specialists' requirements in the specific sphere. The above is claimed in the new concept of teaching foreign languages in universities, where it is emphasized that a foreign language is an integral component of training a modern specialist. Thus, the professional viability of at university graduate is determined in many respects by the degree of his/her uncomplicated and effective participation in a foreign language interactive communication, by the completeness of his involvement in intercultural communication.

The review of scientific and practical literature permits consideration of the concept "academic mobility" as one component of social mobility; as an integrative characteristic of readiness and ability of a future specialist to acquire and improve general (invariant) and professional (variative) competencies and attain a high level of proficiency; as a continuous improvement of their own competency in various forms of future professional paths; as a definition of personal trajectory of vocastional development and effective action in different social-professional societies, self-realization of a student in future profession and self-actualization later in life.

Researchers in the field of the issue emphasize the academic mobility is a complex and multidimensional process of intellectual promotion, not only scientific and cultural knowledge sharing, but also different resources, skills, ideas, technologies, enabling students to form their own professional-educational capacity independently. In this connection, in addition to external factor of importance of academic mobility, we can point to its internal factor, as follows: students' personal interest and willingness to think in a new way, to become a subject of cross-cultural and academic communication, to identify gaps in a specific section of their own knowledge or on the contrary, to be a carrier for new scientific information and technologies.

Viewing the discipline "Foreign language" as an effective mechanism to enhance experience and knowledge sharing in the professional sphere, it should first of all be noted that importance of applying innovative educational technologies in the teaching process of foreign languages in a high school that focus on creative education of a future specialist in the intellectual and emotional context. Developmental teaching, projecting, problem-based learning, level differentiation, test systems, learning in the game, crash course of foreign language culture, learning tools in cooperation, health saving, research, information, communication and object-oriented technologies become priorities for the training process. In accordance with these principles, cognitive universal actions are seen as key elements for educational standard. The reason for this is that a component of mental personal development is considered to be hislher knowledge, which implies established scientific understanding of society and the world, an ability to organize intellectual activity, knowledge of strategies and training tools, development of representative, symbolic, logical, creative thinking, productive memory, concentration, self-reflection. CLIL (Content and Language Integrated Learning) had proved to be one of those potential innovative technologies.

Modern educational methodologies based on good practice specifies the definition of given techniques as follows: it is didactic methodology, designed to cultivate students' linguistic and communicative competencies in a foreign language in the same educational context, as they develop and form common educational knowledge and skills, enabling them to develop their thinking, imagination, social skills and creative ability. Planning the training process based on the given techniques, it should take into account its compulsory features, so-called "4 C - content, communication, cognition, culture".

An analysis of foreign literature shows, that CLIL is correlated with communicative approach that optimized the strengthening of academic content, focused not on long-term results, but on current needs, caused by unfortunate necessity [9].

There is little consistency among researchers regarding CLIL-training without loss of subject knowledge [8]. Currently, the following three models are implementing CLIL:

- foreign language training separately and previously, in the form of training for subjects taught in a foreign language; 
- foreign language training through subject contents, studied in the mother tongue;

- foreign language and specialized discipline training within one course [10].

CLIL approach is currently applied in European higher educational establishments in various fields of the training process. In practice, it appear mostly at the BA and MA level, acting as degree programmes which are either implemented in a foreign language or include extensive modules implemented in the target language. At postgraduate levels, students provide with 'content' modules or individual classes in a foreign language. Language support is provided through not only as direct contact teaching but as also applying blended techniques such as the distanc-learning and e-learning methodology. LSP (Language for specific purposes) and LAP (language for academic purposes) practices are becoming more prevalent than fully integrated methods. Both a native and a non-native speaker of the target languages generally teach the specialized courses, and the substantive interaction between the teacher of specialized discipline and the teacher of a foreign language is actually quite rare. Some universities have developed CLIL practical implementation whereby LSP/LAP courses are proposed as presessional modules to future specialists before they can proceed to their subject studies. Language integration and closer look at the content, with the language support coinciding with what is required in the subject studies is successfully applied in practice. These models also provides for cooperation between language teachers and teachers of specialized disciplines, as either a collaborative planning or team teaching.

The practical experience of foreign universities gained in the implementation of the given educational technique, makes it possible to highlight the following benefits of its using in educational process:

- there is a clear students' motivation increasing to study a foreign language. The learning process is becoming more focused and results oriented, since a foreign language is applied to perform concrete communicative tasks. In communicative situations in a foreign language, students are not able to demonstrate fully their knowledge in specific spheres, lacking in foreign language skills, which prevents them from communicating in professional topics. Therefore, foreign language communicative competency in the vocational context becomes priority for modern university education;

- this would give students the possibility to enhance their knowledge of foreign culture, thus resulting in development of their sociocultural competency. A future specialist receive a rather significant part of linguistic material provided full language immersion;

- moreover, work on the various themes also affords the opportunity for students to learn specific terms that applied to one particular sphere, special structures and stereotyped expressions that not only improves their vocabulary by means of subject terminology, but also prepares them for further study and application of the knowledge and skills that they are acquiring;

- additional advantages of CLIL are the focus on students' vocational training needs and requests, their professional mobility and creative thinking. Methodological and coordination support of the educational process is based mostly on varied curricula, programmes and training materials, interactive teaching forms and methods, individually oriented and differentiated approach to the education process in a high school.

However, despite a number of benefits resulting from CLIL, there are some difficulties of this technique implementing in the training process:

- the teachers of foreign languages have insufficient knowledge on certain disciplines, specialized subjects. Therefore, with a view to successfully implementing the given programmes in a high school, it is necessary to increase the number of qualified teachers, which can conduct lecture studies, practical classes, seminars and laboratory exercises at a sufficiently high level in a foreign language. Foreign language teaching of teachers of specialized disciplines and consultations in the preparatory process of lecture studies and training manuals by teachers of foreign language offered a means of overcoming the problem;

- it should be noted that students have a high level of foreign language proficiency, resulting in a significant workload and certain psychological problems for the students, which are directly related to learning difficulties in a foreign language;

- there is a shortage of training programmes and teaching material, which allow for the full learning potential of future specialist.

In the application of CLIL techniques, certain requirements are applied to a teacher of a foreign language. In the opinion of the survey compilers, a teacher should not only ensure interdisciplinary linkages, but also identify strategies of collegiality and activities with teachers of specialized disciplines to support application of professional terminology, training texts, document layout [6]. The development of student's effective professional mobility requires not only academic material mastering but also active acceptance of ideas of professional readiness, implying foreign language proficiency at a satisfactorily high level.

CLIL methodology calls for developing a new approach to the organizing and teaching the classes. Teachers should actively apply various forms of training materials, educational process, focused on individual and creative activities of students. The process of major specialized disciplines will be cause for 
considerable interest of students and be much more effective, if be carried out in the context of communicative and activity orientated approaches, characteristic of foreign language classes.

Conclusions and perspectives of further research. Academic mobility has been recognized as an essential element of internationalization of higher education in the current circumstances, as a key developmental aspect of international activities of Ukrainian higher education institutions and enhancing their competitiveness in international educational and scientific spheres. Active participation in the academic mobility programmes and international projects require a higher level of foreign language proficiency, notwithstanding the problems listed above regarding the use of CLIL, this technology represents an innovative approach to foreign languages teaching, to respond to the many challenges of the training process in a high school. Taking into account all factors, practical application of CLIL methodology would considerably enhance the students' motivation to learn foreign languages, teach them knowingly and freely use a foreign language in everyday communication; broaden their mind, knowledge and acceptance of the other cultures and values through educational activities in formal and extra-curricular frameworks; prepare students for further education in the area of science; develop and improve linguistic and communicative competencies by learning foreign languages.

\section{References:}

1. Гурье Л.И., Маркина Л.Л. Подготовка преподавателей вуза к инновационной профеессионально-педагогической деятельности. Высшее образование в России. 2009. № 2. С. 91-95.

2. Мирончук Н.М. Академічна мобільність як фрактор інтеграції України у світовий освітній простір. Модернізація вищої освіти в Україні та за кордоном : збірник наукових праць / за ред. С.С. Вітвицької, Н.М. Мирончук. Житомир : Вид-во ЖДУ ім. І. Франка, 2014. С. 20-24.

3. Меньш Е.А. Инновационное моделирование как средство формирования профессиональной иноязычной компетенции. Высшее образование в России. 2013. № 10. С. 90-97.

4. Что такое академическая мобильность? Инфрормационный портал об образовании в России EduGid.ru. URL: https://edugid. ru/spravochnik-abiturientov/499-chto-takoeakademicheskaya-mobilnost (date access: 30.01.2015).

5. Coyle D. Content and language integrated learning motivating learners and teachers. URL: http://blocs.xtec.cat/clilpractiques1/files/2008/11/ slrcoyle.pdf (date access: 30.01.2015).

6. Marsh D. Content and Language Integrated Learning: The European Dimension: Actions, Trends and Foresight Potential. URL: http:// europa.eu.int/comm/education/languages/index. html (date access: 30.01.2015).

\section{Бринцева О. В. Іноземна мова як засіб формування професійної мобільності студентів}

у статmі зроблено спробу розглянути деякі аспекти фрормування профресійної мобільності студентів засобами іноземної мови. Авторка визначає поняття «академічна мобільність» як один з елементів соціальної мобільності та інтегративну якість готовності й здатності майбутніх фрахівців до якісного та швидкого опанування головних (інваріантних) і профресійних (варіативних) компетенцій; як безперервне підвищення рівня своєї компетентності в різноманітних видах майбутньої профресійної діяльності, успішному кар'єрному зростанню; як визначення власної траєкторії професійного розвитку та ефективної діяльності в різних соціально-профресійних аспектах, самореалізацію студента в майбутній професії та житті.

Наголошується на тому, що потенціал іноземної мови не використовується повною мірою у вищій школі, оскільки навчання цієї дисципліни ведеться практично окремо від формування профресійної компетенції майбутнього фрахівия, а також спостерігається відсутність навчально-методичного забезпечення цілеспрямованого фоормування профресійної компетентності студентів засобами іноземної мови.

На основі аналізу практичного досвіду викладання курсу іноземної мови в закордонних вищих навчальних закладах на базі предметно-мовленнєвого інтегрованого навчання CLIL (Content and Language Integrated Learning) розглядаються переваги інноваційного навчання, яке спрямоване на задоволення профресійно-освітніх потреб студентів, розвиток профресійної мобільності та творчого мислення. Автор вказує на деякі проблеми, які виникають під час упровадження технології в навчальний процес, і називає певні вимоги до викладача іноземної мови та організаційного процесу.

Результати розкривають, що одночасне вивчення іноземної мови та профрільної дисципліни $\epsilon$ додатковим засобом досягнення високих освітніх результатів. Технологія CLIL $\epsilon$ інноваційним підходом до навчання іноземних мов у вищій школі, що не лище дає змогу вирішити проблему формування профресійної мобільності майбутнього фахівия, а й істотно підвищує мотивацію студентів до вивчення іноземної мови, дає змогу сфрормувати в них навички свідомого й вільного використання іноземної мови у процесі профресійної комунікації, розширити кругозір студентів, знання та прийняття інших культур і цінностей, сфрормувати й удосконалити лінгвістичні та комунікативні компетенції за допомогою вивчення іноземної мови, подолати мовленнєвий бар'єр як у студентів, так і у викладачів.

Ключовіслова: академічна мобільність, Європейська кредитно-трансфрерна система, предметномовне інтегроване навчання, комунікативна компетенція, іноземна мова, вищий навчальний заклад. 